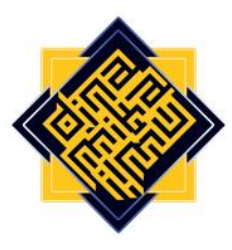

\title{
The Application and its Effects of Lecture Method in the Teaching Process at A Foundation University in Turkey
}

\author{
Tuncay Akçadağ \\ Fatih Sultan Mehmet Vakif University, Turkey \\ e-mail: tuncayakcadag@gmail.com \\ takcadag@fsm.edu.tr
}

\begin{abstract}
In this study, an application used in a lecture at a university was tried to be explained and the effects, thoughts, feelings, and criticisms that occurred in the students as a result of this application were tried to be determined. The steps of the developed application are as follows; the determination of the lesson objectives before the lesson by the teacher, the preparation of the evaluation questions for each lesson objective, the teacher's entering the lesson by directing the evaluation questions to the students at the beginning of the lesson, making a short conversation about the answers given by the students to the evaluation questions, reminding students of the evaluation questions asked at the beginning of the lesson and enabling them to create answers again, comparing the first answers to the evaluation questions with the last answers, and enabling the students to see the differences between the answers. Qualitative research designs were used in the study. The required data were collected through analyzing the answers given to the questions of a semi-structured evaluation form based on the developed application from 73 students in different classes and courses from the education faculty of a foundation university in the 2019-2020 semester. The application was received positively by the majority of the students and their interest in the lectures increased. In addition, there were statements that the students were excited and had fun with the application, and they thought that the application should be expanded.
\end{abstract}

Keywords: lecture method, meaningful learning, presentation method 


\section{Tuncay Akçadağ}

\section{A. Introduction}

Regular activities carried out by the teacher for students' learning are called teaching (Büyükkaragöz \& Çivi, 1994). The differences in individual learning are due to the neurophysiological effects that the stimuli trigger during the learning process which is transmitted to the brain and causes different perceptions (Keskinkılıç, 2007). The general paths chosen to achieve course objectives are called strategies or approaches. The teaching approach consists of decisions about efforts to help students select and organize information that will affect their affective state so that they can learn (Ün Açıkgöz, 1998).

In general, strategies are grouped into four main groups: learning through presentation, discovery, research-examination, and collaborative learning (Ocak, 2011). A method is to transform techniques, content, tools, and materials into services by associating all available resources in order to achieve course objectives based on approaches (Clark \& Starr, 1981). Teaching technique, on the other hand, can be defined as the way of putting the teaching method into practice or the practices done in the classroom for this purpose (Demirel, 2004). Teachers detect the level of learning through assessment and take precautions (Schunk, 2009). Thus, these cyclical actions determine professional teacher-learner relationships. The lecture is a method used in both learnings by reception and teaching by presentation strategies (Sönmez, 2015; Demirkan \& Saraçoğlu, 2016). The lecture method is traditional, teacher-centered; It is a method with a long history in education and is based on explaining the subject to the student (Alpar et al., 2007). Visual and verbal supports should be used during lectures, and there should be logical transitions and internal consistency between verbal propositions. Explanation of the subject should be supported with contradictory examples and propositions; examples should be continued until the subject is sufficiently understood and students gain meaningful knowledge. The mental process to be used in lecturing is deduction, that is, going from a general proposition to a singular proposition. Presentation strategies that adopt the deductive approach are effective in the rapid and safe flow of information (Yılmaz \& Sünbül, 2003; Taşpınar \& Atici, 2002).

It can be said that methods like lecture or presentation lead to learning by rote, and the searches and discussions for the organization of information continue for this type of learning to turn into meaningful learning. Ausubel (1968) explains meaningful learning in his theory based on verbal learning and tries to distinguish between rote learning and meaningful learning. Accordingly, for meaningful learning to occur, new information must be associated and integrated with previously learned information. In rote learning where and how the information will be used is unimportant, whereas in meaningful learning, the learner internalizes the information and organizes the areas where it will be used (Brown, 1994). Achieving the purpose of the lessons seems possible by making the information to be taught useful, meaningful, interesting and entertaining. The first step of this process is to determine the course outcomes and the last step is to complete the course by understanding the level of attainment of these outcomes (Akçadağ, 2018).

In the studies on teaching methods, pre-service teachers stated that they mostly use direct lectures and question-answer methods (Sakallı et al., 2007; Kayabaşı, 2012; Akçay 
Okur et al., 2016; Karasu Avcı \& Ketenoğlu-Kayabaşı, 2019). In addition, the method most preferred by the teaching staff in higher education is the lecture method (Svinicki \& McKeachie, 2011). One reason why the lecture method is one of the most used methods by educators may be that it is easy to implement and can be done by everyone compared to other methods. Although many researchers have spoken against the use of the lecture, it continues to be the main method used in tertiary institutions and with the increasing intake of students; the lecture will remain to a very large extent the main tool for teaching (Marmah, 2014). Lecture method may be used frequently due to its ability to easily convey a subject to large groups, to create opportunities for the trainer, to appeal to emotions, to apply even if the student is not ready, and to be inexpensive. Demirkan \& Saraçoğlu (2016) explored the teaching method was most used by teachers in a high school and the reasons for their preference. As a result of the research, it was determined that the teachers preferred the lecture method the most, but they did not find it sufficient to use only this method and supported it with other techniques. It seems the lecture method is the most common form of teaching in institutions of higher education throughout the world and is likely to continue to be so (Behr, 1988).

It is stated that when using lecture method, it is difficult to take into account the individual characteristics of the students. In addition, usage of lecture method is being criticized because of limitation to only hearing and vision-based applications and students being passive and generally in the position of listeners (Taymaz, 1992). Some constraints of lecture method are if the duration is prolonged, the lesson becomes boring, the teacher is in the center, communication is generally one-way from teacher to student, it is difficult to measure the learning level, and it is more cognitive-oriented (Kaur, 2011; Taşpınar, 2005). The ineffectiveness of the lecture method compared to other methods has disturbed many educators and with many studies they have tried to prove the ineffectiveness of the lecture method (Şenel, 2010; Tay \& Yıldırım, 2013; Özerbaş, 2011; Korkmaz \& Korkmaz, 2020; Taslıdere \& Bedur. 2015).

In the lessons taught with the lecture method, various ways are suggested so that the students do not lose their interest in the lesson. Activities such as definitions, examples, comparisons, expert opinions, statistics, jokes, stories, daily events, memoirs, etc. can be used for verbal support (Sönmez, 2015). Although the use of all these is seen as important steps in attracting the students, they are not elements that directly enable students to learn but are helpful elements in listening to what the teacher tells. The teacher is expected to be knowledgeable in using these supports and to act in accordance with the general principles of education (Gözütok, 2017; Ishiyama et al., 1999). It is thought that an application, which will direct students to the achievements of the course and integrate them with the course by using these elements, when necessary, will contribute to learning.

The question-answer method is the students' answering the questions formulated by the teacher by creating the lesson outcomes and question connection (Küçükahmet, 2009). In learning by discovery, students come to the classroom with a problem that will arouse their curiosity and meet their learning needs (Demirel, 2004). The application can 


\section{Tuncay Akçadağ}

be considered important in terms of associating the mentioned methods with these aspects.

Based on some of the problems experienced in classrooms where lecture method is predominantly preferred, the need arises for an application that allows the students to be involved more in the process, in which teaching is a tool and learning is the main goal, and that can turn the lectures into a learning environment where teachers are in the center in favor of the students. Such applications, their effects and results are needed to be explained.

In this research, an application developed to solve the problems experienced in the course taught with the lecture method in the education faculty of a foundation university was tried to be explained and the effects of this application on the students were tried to be determined. For this purpose, answers to the following questions were sought.

1. What are the problems experienced in the lessons taught with the lecture method?

2. What kind of positive differences occurred with the application?

3. What kind of problems occurred with the application?

4. What are the suggestions for the application process?

\section{B. Research Methodology}

This research was designed as qualitative research. It was carried out to explain an application developed to solve the problems experienced in the lessons taught with the lecture method and to determine the effects of the application in the education faculty of a foundation university. The steps of the application are given below.

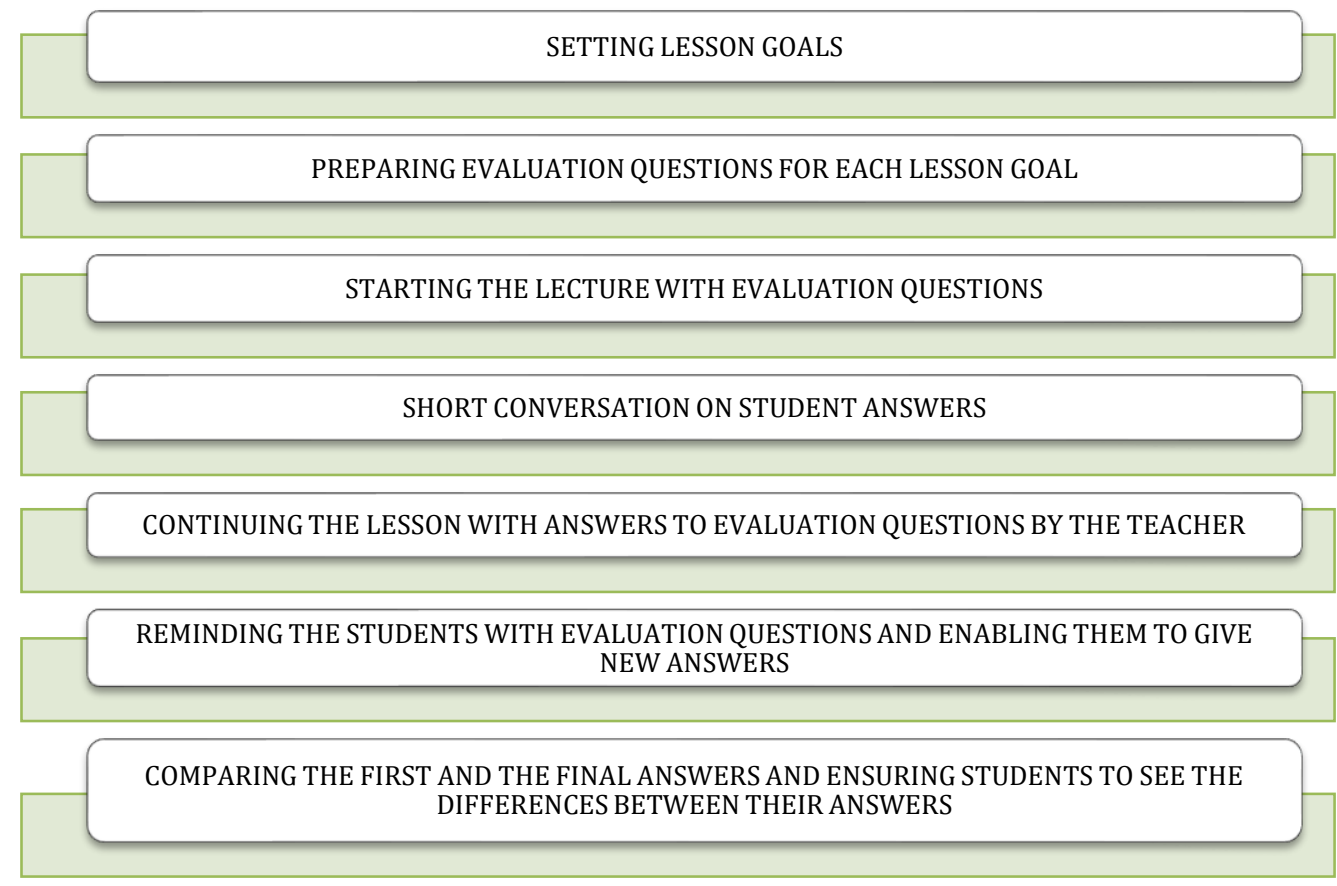

Figure 1. The steps of the application developed for the diversification of a lesson to be taught with lecture method. 
Setting the lesson goals: Considering the duration of the lesson, the teacher expresses the lesson goals that students need to achieve. In this process, it is necessary to determine the objectives in a way that they can be realized during the course, considering the steps of the application.

Preparing evaluation questions for each lesson goal: It is the preparation of evaluation questions related to each lesson objective in order to understand at what level the determined lesson objectives have been achieved at the end of the lesson.

Starting the lecture with evaluation questions: At this stage, after the opening of the course (arousing curiosity, drawing attention), students are asked to write and answer these questions. Students are free to create answers in many ways, those who want can leave the answers blank, those who want can guess the answers, and those who want can write as many answers as they know. Thus, it is thought that this step is a step that enables students to relate to the objectives of the lesson until the end of the lesson.

Short conversation on student answers: In this step, after the students complete their answers to the evaluation questions within the time given to them (10-15 minutes), it is necessary to have short conversations over the answers of a few volunteers or randomly selected students. Thus, while the answers given by the volunteer students to the questions are specified, it is aimed that the other students can be included in the process and they can review their own answers.

Continuing the lesson with answers to evaluation questions by the teacher: In this process, the teacher continues the lesson and gives the answers of the evaluation questions about the objectives of the lesson by using the lecture method. Hence, it is aimed that the students can listen to the lesson through their own answers and create a link between what the teacher tells and their own answers.

Reminding the students with evaluation questions and enabling them to give new answers: In this process, it is aimed for students to understand how much difference there is between the information input provided by the teacher and the information available to the students. Therefore, it is aimed to enable students to create new answers, review incomplete or incorrect answers, and ask questions if they are uncertain about anything.

Comparing the first and the final answers and ensuring students to see the differences between the answers: In this final step, it is aimed to include short conversations that enable students to indicate how far they have achieved their course goals. Thus, it is thought that a movement towards listening to the teacher is provided by participating in the lesson instead of just passively listening.

The following figure shows the process of the application developed for the lesson taught with the lecture method and the interactions that are expected to take place in this process. 


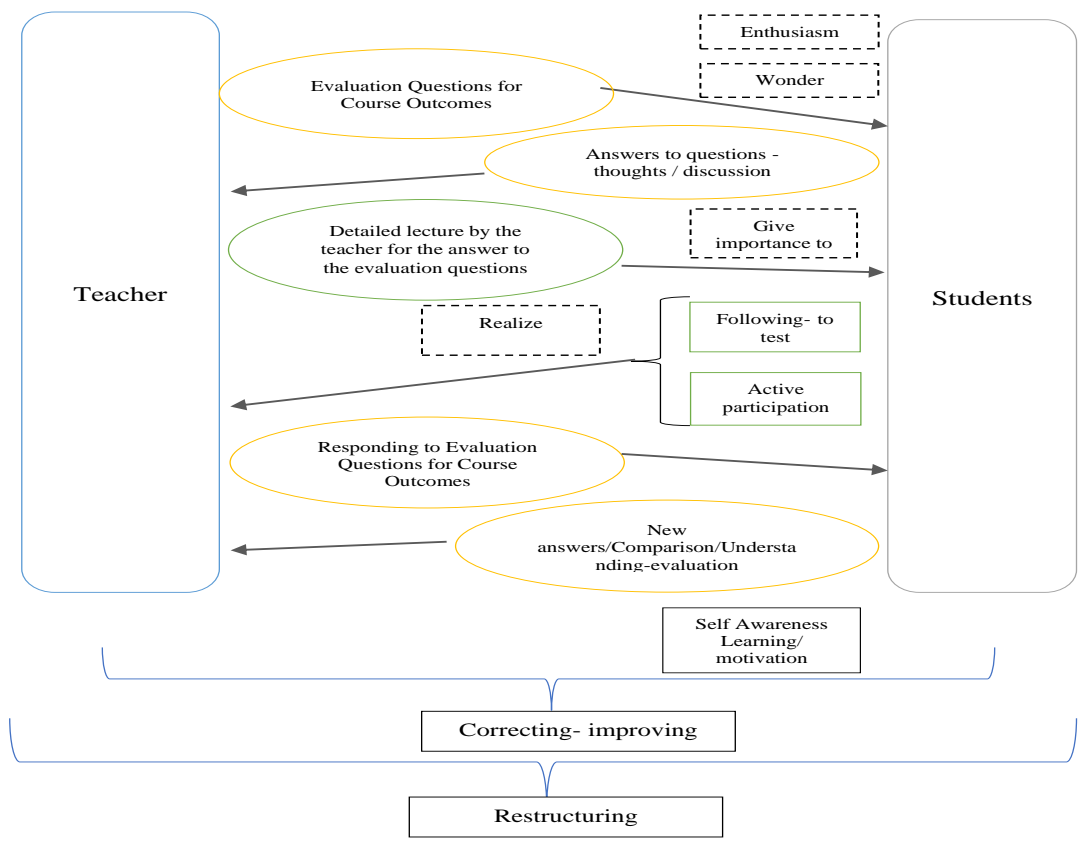

Figure 2. The processes of the application developed for the lesson taught with the lecture method

Above are the processes of the application developed for the lesson taught with the lecture method and the interactions that are expected to occur in the process.

\section{Study Group of the Research}

Neuman (2014) defines the sample group as a group that the researcher wants to research, to have an idea about and that he or she thinks represents the general population. Although it is stated that there is no concern about generalizing to the universe based on a sample in qualitative studies, it may be important that the results of the studies can be predicted, meanings can be made, and analogies can be made about the universe. For this situation to occur, it is important to determine the sample from which detailed data can be obtained for the purpose of the research (Coyne, 1997). For this reason, the sample of the research was determined as the typical sample, with the assumption that the classes taught in the education faculties of the universities are homogeneous structures. Patton (2002) emphasizes that in typical sampling usage, the study environment is not specially chosen, so the location should never be extreme, deviant or unusual.

The study group of the research consists of students in two classes taught in the faculty of education. With this preference, the sample was included in the purposeful sampling/easily accessible features. Being easily accessible means determining the most suitable items as a sample among the existing ones (Singleton \& Straits, 2005). Thus, the 
study was carried out in two classrooms where the researcher gave lectures in the Education Faculty, Educational Sciences, Guidance and Psychological Counseling (EPC) and Basic Education Department, Preschool Teaching (PT) programs at a foundation university. The developed application was carried out in the "teaching principles and methods" courses given to the EPC 1st grade students and the "educational sociology" courses given to the PT 1st grade students. These lessons are determined as two-hour lessons per week. In the subjects distributed in the fourteen-week syllabus, a transfer of knowledge that can be considered as excessive by the teacher should be fit into this time frame as planned. These courses were chosen because of this situation, and a total of 73 students who attended the courses in both classes formed the study group of the research.

It can be said that the classrooms of the researched faculty are generally designed according to the teacher-centered teaching system. In this type of sitting arrangement, there are spaces between the columns in which the rows are arranged one after the other, the students are seated facing the teacher and facing each other's backs (Yale Poorvu Center, 2021), where the teacher decides what to teach and how (Çınar, 2010).

Although it is stated that the situation in teaching, especially by preferring lecture method, varies depending on the lecturer's ability to teach and use humor (Sönmez, 2015), based on the researcher's observations, when the situation is considered in terms of classroom climate and students' moods, there is generally a negative feeling in the classroom environment. For example, observing low- and moderate-level problem behaviors such as students swiping their cell phones during class, napping, looking outside, asking permission to leave the class, drawing something in their notebook or on the papers in front of them can be explanatory in indicating the negativity of the environment.

\section{Data Collection and Analysis Process}

The data analysis process includes steps of preparing the data for analysis, creating the codes, associating the codes with the themes, and presenting the results in tables or texts (Creswell, 2007). Answer papers consisting of students' feelings, thoughts, comments and criticisms about the application were analyzed by separating them with content analysis. Content analysis is the extraction of sub-themes (categories) and themes belonging to the codes from the data. Content analysis is "classifying the message contained in verbal, written and other materials in terms of meaning and/or grammar objectively and systematically, converting them into numbers and making inferences" (Yıldırım \& Şimşek, 2011; Tavşancıl \& Aslan, 2001). Since the participants gave more than one opinion on different questions about the same code, the numerical values of the codes were different from the total number of participants. Determining the number of opinions of the participants is not one of the main purposes due to the method of the research (Miles \& Huberman, 1994). However, it is thought that knowing the density of opinions, developing comments on why the most mentioned themes are mentioned, and the correction and development processes of the applied technique are valuable. 
Table 1. Themes and categories

\begin{tabular}{lc}
\hline Themes & Categories \\
\hline $\begin{array}{l}\text { Problems experienced in the lesson } \\
\text { taught with the lecture method }\end{array}$ & $\begin{array}{c}\text { Teacher centrality } \\
\text { Reluctance } \\
\text { Communication problem }\end{array}$ \\
\hline Positive outcomes of application & $\begin{array}{c}\text { Interest in lesson } \\
\text { Self-awareness } \\
\text { Comparing with other subjects } \\
\text { Communication }\end{array}$ \\
\hline Problems occurred during application & Problems \\
\hline Suggestions for application & Suggestions \\
\hline
\end{tabular}

Table 1 includes the themes obtained from the research questions and the categories created as a result of the analysis of the data.

\section{Credibility and Validity of the Research}

The validity and reliability of the data are tried to be expressed in qualitative research designs with the concepts of credibility, accurate results and the competence of the researcher (Krefting, 1991). Indicators of credibility are stated as prolonged interaction, participant confirmation, and expert review (Holloway \& Wheeler, 2002). The fact that the researcher works as a faculty member and gives lectures in the faculty where the research is conducted, observes the events in the lessons personally, is aware of the students' feelings and thoughts, and provides guidance and friendly relations with them may mean that long-term interaction occurs.

For external validity in qualitative research the results should be transferable to other similar situations, reliable; similar when repeated with similar groups, objective, free from prejudices and confirmable (Başkale, 2016). As external validity, the application of the research in two different classes of two different departments of the faculty of education and the similarity of participant statements regardless of class and department differences can be shown. This may also reflect the reliability of the research. Introducing the classroom environments and the way students participate in the lesson, specifying the conditions of the lesson can be specified as methods of providing external validity. It can be shown that the criticisms and negative aspects of the technique applied as an indicator of objectivity are reflected in the research findings. Another situation in terms of the reliability of the research can be stated as the detailed explanation of the research processes.

\section{Findings}

In this section, the findings regarding the evaluation of an application developed to solve the problems experienced in the lesson taught with the lecture method in the education faculty of a foundation university are given. 


\section{Problems Experienced in Lesson Taught with Lecture Method}

Under this title, the problems expressed in the lecture, which was taught with lecture method, were analyzed. The results of the analysis are given in the table below.

Table 2. Problems Experienced in the Lesson Taught with Lecture Method

\begin{tabular}{lcc}
\hline Categories & Codes & Number of opinions \\
\hline \multirow{3}{*}{ Teacher centeredness } & Just transferring information & \\
& Insufficient participation in class & 68 \\
& Only listening- taking notes & 41 \\
& Not enjoyable & 27 \\
Reluctance & Sleepiness & 65 \\
& Boredom & 59 \\
Communication problem & Tiredness & 45 \\
& One way message & 32 \\
\hline
\end{tabular}

The first sub-problem of the research was "What are the problems experienced in the lesson taught with lecture method?". In the analyzes, the answers to this question were determined by the categories of teacher-centeredness, reluctance and communication.

\section{Teacher-centeredness}

Teacher-centeredness can be explained as the teacher lectures in the lessons and the students participate as passive listeners. Some statements of the participants about this situation are; "...there is a common perception that the teacher will give all the information and we will follow this situation. In my opinion, this situation results in poor quality and inefficiency", "Normally, when I listen only, it definitely does not stay after the first half hour. Especially if it is not an interesting subject, I often have trouble in remembering what I have learned". Another statement regarding the problem experienced in terms of participation in the lesson is as follows: "There is no such thing as attending the lesson when we only listen to the teacher".

\section{Reluctance}

It can be stated that in a teacher-centered lecture course, the students' being passive receivers, usually in the listening position, causes them to lose their attention and just watch the lesson. Some of the views expressed regarding this situation are as follows: "The lesson is unpleasant and time does not pass", "Only the teachers talk and it is very monotonous. We are almost falling asleep" and "...we are exhausted because we wake up early in the morning and attend the class and we become more tired. In that case, how much attention can you give to a slide that lasts for hours and to a lecture in the same tone?"

\section{Communication problem}

Negative statements about students' participation in the lesson and their presence in the lesson were evaluated under the category of communication problems. Considering 


\section{Tuncay Akçadağ}

these expressions, it can be said that communication is generally one-way from teacher to student, and this form of communication creates problems in learning the lesson. One of the expressions emphasizing this situation is "The more teachers talk, the more they want to talk as if something is missing. In such a case, the messages are one-way, from the teacher to the student. Students' opinions are rarely asked..." Another idea was expressed as "usually teachers do not need our ideas". In another statement, the communication problem was addressed with the view that "while listening to the lecture, there is such an atmosphere in the classroom that even if you have something to add, you give up and question "why would I say it?"'!"

\section{Positive Differences with The Application}

The data regarding the positive outcomes of the application are given in the table below.

Table 3. Positive Differences with The Application

\begin{tabular}{|c|c|c|}
\hline Categories & Codes & $\begin{array}{c}\text { Number of } \\
\text { opinions }\end{array}$ \\
\hline \multirow{4}{*}{ Interest in lesson } & Active participation & 66 \\
\hline & Curiosity and excitement & 35 \\
\hline & Readiness & 23 \\
\hline & Exam relation & 13 \\
\hline \multirow{5}{*}{ Self awareness } & Speaking out ideas & 52 \\
\hline & Self-assessment & 52 \\
\hline & Awareness of learning & 51 \\
\hline & Realizing self-traits & 24 \\
\hline & Preparation and deciding for lessons & 21 \\
\hline \multirow{4}{*}{$\begin{array}{l}\text { Comparing with other } \\
\text { subjects }\end{array}$} & Active student participation & \\
\hline & Permanence of learned & $\begin{array}{l}77 \\
62\end{array}$ \\
\hline & $\begin{array}{c}\text { subjects } \\
\text { Fun learning }\end{array}$ & 60 \\
\hline & More interest for lesson & 55 \\
\hline \multirow{3}{*}{ Communications } & More dialogs & 73 \\
\hline & Learning other ideas & 32 \\
\hline & Opportunity for expression & 13 \\
\hline
\end{tabular}

The second sub-problem of the research is "What kind of positive differences occurred with the application?". The categories and the codes related to them and the number of opinions on the codes regarding what kind of differences occur with the 
application made regarding this problem are given in Table 3. Below are explanations regarding the findings in Table 3.

\section{Interest in Lesson}

They stated that at the beginning of the lesson, right after the greeting, the teacher talked about the goals of the lesson and asked the students the evaluation questions about these achievements, and then after this beginning, the majority of the students stated that the interest in the lesson increased and the practice led to active participation in the lesson. A few statements regarding this situation are as follows:

"Before the lesson started, teacher had aroused curiosity and increased the interest in the lesson. Because we were going to comment on a subject that we had not covered before."

"My interest in the course increased with a sense of curiosity. Thinking while answering the questions and then waiting to see if the answers would fit kept my interest in the lesson alive..."

Students stated that this aroused curiosity and created an expectation to test the accuracy of their answers in the following parts of the course. In fact, the intriguing expression of a student who can be interpreted as being uninterested in the course was "My attention was inevitably drawn to the course...".

When the expressions are examined, it can be said that the students established a connection with the goals of the lesson. One student said, "It is effective and efficient in terms of forming a preliminary idea about the subject. It increases the participation in the lesson". Moreover, another person described the situation with the statement "Asking questions about the lesson and guessing what the answer is before the lesson makes you inevitably interested in the lesson".

It can be stated that the students generally have a habit of only listening to the teacher, with such a start, a situation that contradicts this habit occurs, they become active participants rather than passive listeners, and they tend to think about the lesson, produce ideas and answer the questions asked.

Some views of students are as follows; "... usually felt sleepy, but this lesson kept me awake", "...the question about the subject before learning about it aroused my curiosity and interest", "...since we do not participate in the lesson in general, I can say that such an entrance makes us more active" can be cited as a source for these findings.

At the beginning of the lesson, after the teacher had asked the evaluation questions about the lesson goals, got their answers, had short conversations on the answers and shared the ideas, the interest and excitement continued, the students tried to understand the lesson more. Students especially tried to learn the answers for the questions because similar questions may be asked in a future exam. Some student statements are given below.

"Although the work on thinking about the questions and being able to answer them in this context made us a little hesitant, and although they were answered in an 
Tuncay Akçadağ

uninformed way when we looked at the result, it actually enabled us to find answers close to the correct ones with the knowledge and reasoning that people have acquired"

"It has been a method to improve our thinking. It helped us think more broadly."

"I listened to the exam questions in a way that I kept the answers in mind, in case they were among these questions. I hope I did it right"

"... I had to listen to the lesson well because the questions were likely to come up in the exam"

"If it is continued, the success rate in the exams will increase".

In addition, it was stated that such a lecture can lead to permanent knowledge, enable reasoning, increase in active participation in the lesson, and have positive aspects. Examples of these expressions are given below.

"It's a method that keeps information in mind in general. Saying our answers out loud makes it easier to remember later."

"It is important in terms of making the student active and developing their thinking power".

\section{Self-awareness}

Students said that they were able to evaluate themselves with the application. One statement was "...I was enthusiastic and interested as I found an answer". Besides, in another view it was stated that "...I realized that even to produce an idea, knowledge is needed..." and "...it means that my ideas can be wrong...". Some other interesting expressions under this category were; "...as a student, I spent time trying to understand the lesson for the first time", "...I tried to connect what we learned with the other lessons..." and "...I felt that I learned something...I couldn't expect such a thing".

One of the statements that showed students' enjoyment and satisfaction was "...I was in the lesson physically and mentally...", another was stated as "...there could be things other than keeping quiet and taking notes in the lessons...".

Most of the students said that they enjoyed the process and felt valued. One student stated; "...you prepared before the lesson. You are curious about our ideas and you listen to us. People feel valued". Another student replied as; "... a suitable environment has been created for our ideas to be exposed and valued...".

In addition, as a result of students' self-evaluation, statements about coming to the lesson more prepared should the application be implemented to the lessons again and making decisions about how they can do better are also included. One student said, "...it brought me one step closer to the issue of coming to class prepared. I have to study and be prepared for the next time...".

\section{Comparing with other subjects}

In the analysis process, it was found that the participants compared the lessons in which the application was carried out with other, and it was expressed as another 
category. One of the statements about students being more active and participating in the lesson compared to other subjects is; "In this method, you both test yourself and learn more about the subject by actively participating. There was no such situation before". Another statement was "Many of my friends, including myself, start to mess with our mobile phones after the first 10-15 minutes in most classes. While we are giving our ears to the teacher, our minds are elsewhere. In this application, my mobile phone did not come to my mind". Some other expressions are "...it is an extremely good method compared to the lectures taught only in theory...", "I can say that it is much better than the method only the teacher speaks", "In other lessons, only the teachers speak and it is very monotonous. We sleep. I think this method of teaching is more appropriate", "...it is not only teacher-oriented", "Teaching the lesson in this way is much more useful and much more informative than just listening to the lesson and highlighting the book".

Some of the practical views are related to the fact that the information learned by this method may be more permanent than the others. Undoubtedly, there is no measurement about the permanence of what has been learned. Among the findings, such discourses draw attention and students express their feelings about this issue. One of these statements is, "Normally, when I just listen, there is absolutely no rest after the first half hour. Most of the time I have trouble remembering what I have learned, especially if it is not an interesting subject. But with this method, it is remembered for a long time, so it becomes a permanent learning." Another statement that supports this situation can be stated as "...comparing with other lessons I think it is unlikely to forget what I learned in this lesson".

One of the criteria for comparison with other courses was the lesson being fun and enjoyable. One of the statements is as follows, "...the lesson became fun instead of boring". To give another example, a student said "...it was the most enjoyable lesson we have ever been taught. I couldn't understand how time passed". In another statement a student shared her feelings saying "there is competition, excitement and there is a wait to see if your ideas are successful or not. Just like in games of chance".

One of the most remarkable situations was the fact that students who are generally uninterested in the course become more interested with the practice. One student said; "Reluctant students are also more interested in the lesson and they experience the lesson oneto-one. As the interest increases, the number of conscious students will also increase".

\section{Communication}

After the application, the participants expressed the differences in communication between the teacher and the student. These findings are listed under the communication category. Students said that there was more dialogue in teacher-student communication. The participants' statements such as "...enables active participation, positively affects communication", "...It is also beneficial in terms of communication between the teacher and the student", "I think asking and answering questions positively affect communication" can be taken as a sign of the increase in communication in class. 
Tuncay Akçadağ

Another situation evaluated under the communication category is that the participants had the opportunity to learn about other ideas in the classroom, and that the students had the opportunity to express and discuss their own thoughts. Some of the statements that support this finding are "... I learned my friends' opinions, too", "...I think it is positive in terms of both expressing myself and speaking in public", "I can create what I know in addition to an answer that I researched for myself. Also, I can express myself more easily and think in more detail."

\section{Problems occurred during application}

The data regarding the problems occurred during application are given in the table below.

Table 4. Problems Occurred During Application

\begin{tabular}{lcc}
\hline Categories & Codes & $\begin{array}{c}\text { Number of } \\
\text { opinions }\end{array}$ \\
\hline \multirow{3}{*}{ Problems } & Surprised-nervous & 8 \\
& Struggled & 5 \\
& Not suitable learning style & 7 \\
& Continuity of Application & 3 \\
\hline
\end{tabular}

When the statements about what kind of problems occurred during application were examined, a group of students stated that they were surprised and nervous when the teacher asked the students to write the questions at the beginning of the lesson and to find answers to these questions based on their thoughts. One of the students said, "I felt bad about some questions because I had no idea, about the subject. Some questions sounded like I already knew. Most of my answers did not match with the correct answers, but I followed the lesson carefully." Furthermore, another one said, "Because I did not have a good understanding on the subject, I was tense at first and did not know how to answer." One student expressed his nervousness as "... good, but on the other hand, it increases my stress. I wonder if I can answer, or to what extent my answer is correct. It can be a sad situation if the answer is not understood correctly...".

A small number of students stated that they did not know what to write and had difficulties while answering the questions about the achievements at the beginning of the lesson. Some of the expressions related to this situation are as follows: "First of all, if I have no idea about the subject, the idea of hopelessness arises at first", "... well, the subject is too scattered, thoughts about meaningless subjects arise. That's why we're struggling."

Some students said that the application was not suitable for their learning style. This point of view was expressed by one of the students saying, "I think that this method takes too long since I am a person who prefers to listen and takes notes and learns better in this way". Another student said, "It may be good for eager students. Continuity can be boring. Some other methods should be used too! Writing down all the time is not good for me," and also another student's idea can be added as an example, "It might be nice, but I don't like speaking in class." 
While one of the views on how often and in what kind of courses this application can be made was "It can be used in lessons where questions to be commented on can be asked, although not in all lessons", another opinion was "...this method should be applied in every lesson".

For a few students, this practice may have created a situation that was challenging or incompatible with their learning style. This result is expected in terms of research and is considered normal. For example, students with dominant tactile/kinesthetic features are bored of sitting for a long time, they prefer to use muscle movements while learning and learn outside the classroom rather than learning in the classroom, students with dominant auditory learning characteristics need to listen rather than write, and to speak and explain more in order to say, "I learned" (Arslangilay, 2015).

\section{Suggestions for the Application}

The data regarding the suggestions of the participants on how the application could be better are given in Table 5 .

Table 5. Suggestions for the application

\begin{tabular}{lcc}
\hline Categories & Codes & $\begin{array}{c}\text { Number of } \\
\text { opinions }\end{array}$ \\
\hline \multirow{3}{*}{ Suggestions } & Lecture with stories, memories, case studies & 14 \\
& Frequency of use of the application & 3 \\
& & 6 \\
\hline
\end{tabular}

In this section suggestions for the application are examined. Some students suggested that it would be better if the teacher would diversify the related question with situations such as story, memoir, case study, as if describing the topic instead of just giving the correct answers. One of these statements was, "In order for it to be positive and more effective, I need stories, memories, empathy, etc. It is necessary for the teachers to reinforce the subject with things like these". Another student expressed his suggestion by saying "I think it is very necessary to give examples from real life in terms of understanding the subject and remembering it later".

Students also suggested that the evaluation questions should have been asked with some clues and tips. One of the expressions related to this suggestion, which is in accordance with the wishes of the students who are confused and nervous about what to write in response, is as follows: "...it might be better if we tried to find out by giving tips...". Another idea is asserted in this way "questions make us think about the subject, but not being able to answer causes stress. That's why some facilitators should be provided while responding. For example, a clue can be given for each question".

Six of the students suggested that the application would not be suitable for every lesson and it would give better results in some lessons. Some of these expressions are as follows: "It may be good for eager students. Continuity can be boring. Some other methods should be used too! Writing down all the time is not good for me,", "In such an application, it is 


\section{Tuncay Akçadağ}

necessary to come to the lesson prepared", "Although not in all lessons, it can be used in lessons where questions to be commented on can be asked."

\section{Discussion}

There are some studies and suggestions for reducing the limitations and improving the quality of a general teaching method in which the teacher speaks, and the students listen. One of these studies was done by Cashin (2010). Cashin proposes a series of activities to improve the quality of a lecture: "determine your learning goal, choose a format, outline your lecture notes, choose examples carefully, add notes for yourself, explain the points you want to tell with the audience in mind". In addition, he emphasized how the lecture method would be effective with the titles of presentation and clarity, interest and motivation, feedback and interaction. In this study we have used similar techniques such as the determination of learning goals, interest and motivation, feedback and interaction. Cashin's suggestions do not include converting passive students into active listeners. However, the most important factor in our study was to somehow ensure student participation. Cashin wrote in his article "Watch your students as they are lectured. Do they seem to follow what you say? Do they take notes? Do they seem confused or not understanding? One caveat: If a few students are napping, reading the school newspaper, surfing the Internet, or not engaging in class, it's their choice and responsibility, not ours. We cannot force them to learn!". However, it can be said that a structure-mechanism created for a situation is determinant in the formation of the behaviors of the people who follow it. Based on the idea that the responsibility of the system is great and important, it is thought that it is not fair to impose the responsibility of students' resistance to learning or their unwillingness to learn. For this reason, we tried to create a mechanism-structure with the application we discussed. This mechanism generally aims to attract their attention to enable them to participate in the lesson and at the same time to create an opportunity for them to have fun. Considering the feedbacks or statements received from the students, it can be said that this aim has been achieved.

Drawing the attention of the students at the beginning of the lesson is considered as one of the most important activities that can be done in this regard. Such activities will direct them to the purpose of the lesson, and thus creating a need for learning (Coultas \& Lewin, 2002; Özçelik, 2010). These activities should be organized by keeping students away from anxieties such as embarrassment, fear of failure, avoidance of criticism, and humiliation (Başar, 2004). When the findings are examined, the application had positive effects on most of the students. It is understood that the subject moved away from the concerns, that the students were curious in this process and were excited to check the accuracy of their answers. The formation of expectations in students about what they will learn in the lesson helps them to choose the information to be learned and saves them from going out of the subject (Senem oğlu, 2003; Fidan, 1996).

In the applied technique, the transition phase to the lesson consisted of taking the answers given by the students, trying to understand what they meant, and forming comments on the answers in the classroom. The classes were crowded, and the time 
allocated for this activity was limited to 10-15 minutes. Volunteers and randomly selected participants were asked about their answers to the questions. Although this created anxiety and excitement in a few students, it was received positively by most of the students. Başar (2004) states that "students know that they will be asked something at any moment and their opinions are taken; can make the course attractive for students". Asking students some assessment questions about course objectives and asking for their answers is also intended to activate prerequisite learning.

Prerequisite learning requires connecting with previous learning in order for learning to take place. Before moving on to new learnings, previous learnings are recalled to shortterm memory, thus establishing a connection with the new information to be learned (Gagné \& Driscoll, 1988; Senemoğlu, 2003). In the statements about asking the students to write the answers by asking evaluation questions about the achievements, it was stated that previous information was checked, and answers could be created about an unknown subject by using previous learnings. According to Sönmez (2015), this stage of the application coincides with the transition to the course, which is the last stage of the course introduction activities. Sönmez states that at this stage, the teacher can organize tools such as facts, events, memories, plates, tables, maps. Motivation of students towards learning is important at the beginning of the lesson as well as at every stage of the lesson (Taşdemir, 2000). At this stage, the importance of learning in the course and what these learnings will do are explained (Özbek, 2007). Therefore, by answering the evaluation questions about the objectives of the lesson, the students reach the lesson objectives and information about what they will learn at the end of the lesson. In this way, it is thought that the motivation of the students towards the subjects is ensured.

The question-answer technique is a technique that is based on the teachers' directing the questions to the students while lecturing, the students' verbal answers, and it is a technique to control whether what the teacher tells is conveyed correctly to the receiver (Küçükahmet, 2009; Pınar, 2017). Küçükahmet indicated the purposes of this technique as stimulating analytical thoughts, diagnosing student difficulties, motivating students, clarifying concepts, explaining the reasons for results, encouraging students to make selfevaluations, and encouraging the application of concepts. Since the classrooms where the research was conducted were shaped according to the teaching situation with the lecture method, it does not seem appropriate to introduce another method. For example, desks are fixed and designed as lecture theatre. For this reason, it is quite usual that the teacher is in the center and takes an active role in teaching lessons. In this context, the practice of presenting the objective evaluation questions to the students in written form before the lesson is taught and getting answers in the same way, which we discussed in this context, is matched with the purpose of stimulating analytical thoughts, motivating the students, creating opportunities for self-evaluation with the question-answer technique explained above, but does not coincide with the aims of diagnosing student difficulties and the aims of encouraging the concepts to be applied.

Learning provided by creating curiosity can lead the learner to seek meaning, use information, and distance themselves from rote learning, and students' matching of what 


\section{Tuncay Akçadağ}

they have learned with their previous knowledge and their search for meaning are related to deep learning (Ekinci, 2008). Some of the student statements were expressing the idea that if such a study continued, the exam grades would automatically increase. In this study, no emphasis was placed on getting high grades or working for grades. The main purpose is to learn the subject fully, to internalize the information, to realize where and how to use it, and to understand its essence. This aim can also be associated with "deep learning", which is the students' questioning of information and trying to find its logic, as stated by Yılmaz \& Orhan (2011).

The conclusion part of the lecture consists of three steps. These are the final summary, re-motivation, and closure. It is stated that the main and auxiliary points should be emphasized in the last summary step, the motivation at the beginning of the lesson should be repeated in the motivation section, and the questions asked in the drawing attention stage should be asked again in the closing section. The teacher should use hints, feedback and corrections in this process, and what is required in the next lesson, if any, is reported. In the evaluation part of a lecture, a measurement tool with at least three questions should be used, the student should not be graded, mistakes should be shown to him and necessary corrections should be made (Sönmez, 2015). In practice, the evaluation questions posed to the students at the beginning of the lesson and asking them to answer again at the end of the lesson can be matched with Sönmez proposing, "Use a measurement tool with at least three questions that measure target behaviors, do not give grades to the student, and show him/her mistakes and making necessary corrections". In addition, there are some differences according to this flow in the application discussed. The purpose of asking questions on a topic that has not yet been covered at the beginning of the lesson is to make students aware of their own learning and to act on this basis. In this section, the aim of the lesson is to make the students aware of their learning and to ensure their active participation in the lesson.

There are three basic stages in the planning of the teacher approach through presentation: (1) the stage in which the objectives are determined, (2) the stage in which the subject is determined, and (3) the stage in which the examples are selected and prepared (Bilen, 1999). The attention of students can be increased if the lecture includes some short activities for students such as brief small-group discussions or simple problem solving. Any change in activities may renew attention. Therefore, the receipt of information is an important feature in the process of lecturing which has to be considered by the instructor (Kaur, 2011). During the application, what is intended to be taught should be clarified and the existing knowledge should be linked with the knowledge to be taught (Ausubel, 1969).

With the implementation, the first two of the three items in the planning stage specified by Bilen were met. It can be said that the situations mentioned by Kaur were realized. Directing the students to remember the previous information about the subject by directing the evaluation questions to the students without giving the lecture coincides with Ausubel's explanation that the current information should be linked with the information to be taught. 


\section{E. Conclusion}

The students who participated in the application stated that the lessons were teacher-centered, so they were reluctant towards the lessons, and there was a communication problem between them and the teacher. Due to the application, it was indicated that participation and the interest in the lesson increased; students had permanent and fun learning, dialogue in communication, and opportunity to express themselves. It was concluded that a small number of students were surprised and tense about what kind of problems they experienced with this application. They had difficulties in the studies with the application since some of the studies did not comply with their learning styles. Suggestions for the application include information that it would be good to diversify the lesson with stories, memories and case studies during the lecture. Furthermore, some clues can be given in answering the questions, and using the application more often would be good for ensuring permanence in learning.

Similar applications can be considered and put into action together so that students will also express their opinions. In addition, based on the research findings, what changes and additions can be done for students dominantly having tactile and kinesthetic learning styles can be studied.

\section{BIBLIOGRAPHY}

Akçadağ, T. (2018). lyi öğretmen doğru okul. Anı Publishing.

Akçay Okur, N., Akçay, A., \& Kurt, M. (2016). Ortaokul öğretmenlerinin öğretim yöntem ve tekniklerine yönelik görüş ve yeterliklerinin incelenmesi. Eğitim ve Öğretim Araştırmaları Dergisi, 5 (1). 333-342.

Alpar, D., Batdal, G., \& Avcl, Y. (2007). Öğrenci merkezli eğitimde eğitim teknolojileri uygulamaları. Hasan Ali Yücel Eğitim Fakültesi Dergisi, 7, 19-31.

Arslangilay, A. S. (2015). Öğrenme ve öğretim stilleri, S. Güven \& M. A. Özerbaş (Ed.), Ögretim ilke ve yöntemleri içinde (S. 59-113), Pegem Akademi Publishing.

Ausubel, D. P. (1968). Educational psychology: A cognitive view. Holt, Rinehart And Winston.

Başar, H. (2004). Sınıf yönetimi. Anı Publishing.

Başkale, H. (2016). Nitel araştırmalarda geçerlik, güvenirlik ve örneklem büyüklüğünün belirlenmesi. Dokuz Eylül Üniversitesi Hemşirelik Fakültesi Elektronik Dergisi, 9 (1), 2328.

Behr A. L. (1988). Exploring the lecture method: An empirical study. Studies in Higher Education, 13 (2), 189-200.

Bilen, M. (1999). Plandan uygulamaya öğretim. Anı Publishing.

Brown, H. D. (1994). Principles Of Language Leaming And Teaching (Fifth edition). Prentice Hall Regents.

Büyükkaragöz, S., Çivi, C. (1994). Genel öğretim metotları. Atlas Bookstore.

Cashin, W, E. (2010). Effective Lecturing. Idea Paper, 46 (1), 1-6.

Clark, L. H., Starr, I.S. (1981). Secondary and middle school teaching method. Mac Millan Publishing Co. 
Tuncay Akçadağ

Coultas, J. C. \& K. M, Lewin. (2002). "Who becomes a teacher? The characteristics of student teachers in four countries". International Journal Of Educational Development, $22(3-4), 243-260$.

Coyne, I. T. (1997). Sampling in qualitative research. Purposeful and theoretical sampling; merging or clear boundaries? Journal Of Advanced Nursing, 26 (3), 623-630.

Creswell, J. W. (2007). Qualitative inquiry and research design: choosing among five approaches. Sage.

Çınar, İ. (2010). Sınıf coğrafyası: Geleneksel derslikte kim, nerede oturur? The Journal of International Social Research, 3 (10), 200-212.

Demir, S. (2011). Öğrenme-öğretme yöntemleri ve teknikleri (Editör: Uzunboylu, H. \& Öner, G.) Öğretim ilke ve yöntemleri içinde. Lisans Publishing.

Demirel, Ö. (2004). Eğitimde program geliştirme. Pegem Akademi Publishing.

Demirel, Ö. (1996). Genel öğretim yöntemleri. USEM Publications-11.

Demirkan Ö. \& Saraçoğlu, G. (2016). Views of Anatolian high school teachers about teaching methods and techniques they use in class. The Journal of International Lingual, Social and Educational Sciences, 2 (1), 1-11.

Ekinci, N. (2008). Üniversite öğrencilerinin öğrenme yaklaşımlarının belirlenmesi ve öğretmeöğrenme süreci değişkenleri ile ilişkileri. [Yayınlanmamış Doktora Tezi]. Hacettepe Üniversitesi.

Fidan, N. (1996). Okulda öğrenme ve öğretme. Alkım Publishing House.

Gagné, R.M. \& Driscoll, M. P. (1988). Essentials of learning for instruction (Second edition). Prentice Hall.

Gözütok, F.D. (2017). Öğretim ilke ve yöntemleri. Pegem Akademi Publishing.

Holloway, I. \& Wheeler, S. (2002). Qualitative Research in Nursing. Blackwell Science

Ishiyama, J.T., Mcclure, M., Hart, H., Amico, J. (1999). Critical Thinking Disposition And Locus Of Control As Predictors Of Evaluations Of Teaching Strategies. College Student Journal, 33 (2), 269-277.

Karasu-Avcı, E., Ketenoğlu-Kayabaşı, Z. E. (2019). Sınıf öğretmenlerinin derslerinde kullandıkları yöntem ve tekniklere ilişkin görüşleri: Bir olgubilim araştırması. Hacettepe Üniversitesi Eğitim Fakültesi Dergisi, 34 (4), 926-942.

Kayabaşı, Y. (2012). Öğretmenlerin öğretim sürecinde kullandıkları öğretim yöntem ve teknikleri ile bunları tercih etme nedenleri. Balıkesir Üniversitesi Sosyal Bilimler Enstitüsü Dergisi, 15 (27), 45-65.

Kaur, G. (2011). Study and analysis of lecture model of teaching. International Journal of Educational Planning \& Administration, 1 (1), 9-13.

Keskinkılıç, K. (2007). Eğitim bilimlerine giriş. Sempati Publications.

Korkmaz Ö. \& Korkmaz Ö. (2020). Teknoloji destekli örnek olay yönteminin etkililiği: Ortaokul Türkçe dersine dönük deneysel bir çalışma. Asian Journal of Instruction, 8 (1), 32-46.

Krefting, L. (1991). Rigor in qualitative research: The assessment of trustworthiness. The American Journal Of Occupational Therapy, 45 (3), 214-222.

Küçükahmet, A. (2009). Öğretim ilke ve yöntemleri (Yirmi üçüncü basım). Nobel Publishing. 
Marmah, A. A. (2014). Students' perception about the lecture as a method of teaching in tertiary institutions. Views of students from college of technology education, Kumasi (Coltek). International Journal of Education and Research, 2 (6), 601-612.

Miles, M. B., \& Huberman, A. M. (1994). Qualitative data analysis: An expanded sourcebook. Sage.

Neuman, L. W. (2014). Social research methods: Qualitative and quantitative approaches (Seventh edition). Pearson Education Limited.

Ocak, M. A. (2011). Öğretim tasarımı. Anı Publishing.

Özbek, R. (2007). Öğrenme-öğretme süreci. (Ed. G. Ocak). Öğretim ilke ve yöntemleri içinde. Pegem Akademi Publishing.

Özçelik, D. A. (2010). Eğitim programları ve öğretim: Genel öğretim bilgisi. (İkinci baskı). Pegem Akademi Publishing.

Özerbaş, M. A. (2011). Yaratıcı düşünme öğrenme ortamının akademik başarı ve bilgilerin kalıcılığa etkisi. GÜ, Gazi Eğitim Fakültesi Dergisi, 31 (3), 675-705.

Taşlıdere, E. \& Bedur, S. (2015). Effect of conventional lecturing on pre-service science teachers' understanding about the interaction of light with the lenses. Mehmet Akif Ersoy Üniversitesi Eğitim Fakültesi Dergisi, 1 (33), 105-129.

Taymaz, H. (1992). Hizmet içi eğitim. Pegem Akademi Publishing.

Patton, M. Q. (2002). Qualitative research and evaluation methods. Sage Publishing

Pınar, M. P. D. (2017). Fen bilimleri öğretimi. Pegem Akademi Publishing.

Sakallı, M., Hürsen, Ç. \& Özçınar, Z. (2007). The frequent use of teaching strategies/methods among teachers according to the teacher candidate's observation. Cypriot Journal Of Educational Sciences, 2 (1), 1-8.

Senemoğlu, N. (2003). Gelişim öğrenme ve öğretim: Kuramdan uygulamaya. Gazi Publishing House.

Singleton, R. A., \& Straits, B. C. (2005). Approaches to social research (Fourth edition). Oxford University Press.

Svinicki, M., \& McKeachie, W. J. (2011). Teaching tips: Strategies, research, and theory for college and university teachers (Thirteenth edition). Wadsworth.

Sönmez, V. (2015). Program geliştirmede öğretmen el kitabı. Anı Publishing.

Şen, Ş. H. (2011). Öğrenme öğretme stratejileri (Ed. S. Büyükalan Filiz). Öğrenme öğretme kuram ve yaklaşımları içinde. Pegem Akademi Publishing.

Şenel, H. (2010). Fen bilgisi öğretmen adaylarının çevre bilincinin geliştirilmesinde probleme dayalı aktif öğrenmenin etkisi. [Yayınlanmamış Yüksek Lisans Tezi]. Balıkesir Üniversitesi.

Taşdemir, M. (2000). Eğitimde planlama ve değerlendirme: Kuramdan uygulamaya. Ocak Publishing.

Taşpınar M. \& Atıcı, B. (2002). Öğretim model strateji yöntem ve becerileri/teknikleri: Kavramsal boyut. Eğitim Araştırmaları, 2 (8). 207-215.

Tavşancıl, E. \& Aslan, E. (2001). Sözel, yazılı ve diğer materyaller için içerik analizi ve uygulama örnekleri. Epsilon Yayınevi. 
Tuncay Akçadağ

Tay, B. \& Yıldırım, K. (2013). Bilgisayar destekli öğretimin hayat bilgisi öğretimi dersinde başarıya etkisi ve yönteme ilişkin öğretmen adaylarının görüşleri. Uşak Üniversitesi Sosyal Bilimler Dergisi, 6 (1), 84-110.

Ün Açıkgöz, K. (2003). Aktiföğrenme. Eğitim Dünyası Publication House.

Ün Açıkgöz, K. (1998). Etkili öğrenme ve öğretme. Kanyılmaz Printing House.

Yale Poorvu Center (2021). Classroom seating arrangements, Retrieved from https://poorvucenter.yale.edu in 25th August 2021.

Yıldırım, A. \& Şimşek, H. (2000). Sosyal bilimlerde nitel araştırma yöntemleri. Seçkin Publishing.

Yılmaz, M. B. \& Orhan, F. (2011). Ders çalışma yaklaşımı ölçeğinin Türkçe formunun geçerlik ve güvenirlik çalışması. Eğitim ve Bilim, 36 (159), 69-83.

Yılmaz, H. \& Sünbül, A. M. (2003). Öğretimde planlama ve değerlendirme. Mikro Publications. 